\title{
Tavuk Yumurtası ve Kolesterol Gerçeği
}

\author{
Derya AYDIN ${ }^{1}$, Sami Musa RASHID ${ }^{1}$, Rahim AYDIN ${ }^{2 *}$ \\ ${ }^{1}$ KSÜ, Ziraat Fakültesi, Zootekni Bölümü, Kahramanmaraş \\ ${ }^{2}$ BÜ, Veteriner Fakültesi, Hayvan Besleme ve Beslenme Hastalıkları Bölümü, Balıkesir
}

Geliş (Received): 23.05.2014

Kabul (Accepted): 24.10.2015

\begin{abstract}
Özet: Tavuk yumurtası, iyi bir besin kaynağıdır ve sağlıklı beslenme için gereksinim duyulan birçok esansiyel amino asit ve yağ asitleri ile vitamin ve mineralleri bünyesinde barındırır. Dünyada, özellikle de endüstriyel ülkelerde, yüksek oranda ölüm nedeni olarak kabul edilen kalp-damar hastalıklarının (KDH) yüksek kolesterol içeren gıdalardan ileri geldiğinin bildirilmesi, "kolesterol fobisi"ne neden olmuş ve yumurta tüketimini olumsuz yönde etkilemiştir. Buna rağmen yapılan çalışmalarda yumurta kolesterolü ile kan kolesterolü arasında kesin bir ilişki bulunamadığından Amerikan Kalp Birliği tarafından bugün kolesterol alımının günde $\$ 300 \mathrm{mg}$ olması durumunda insanların günde bir yumurta tüketilebileceği bildirilmektedir. Kolesterol artışına sebep olur korkusu nedeniyle bugün istenen seviyede olmayan yumurta tüketiminin tavsiye edilmesi, insan beslenmesi açısından son derece önemlidir.
\end{abstract}

Anahtar Kelimeler: Kan kolesterolü, KDH, kolesterol fobisi, yumurta tüketimi

\section{Chicken Eggs and Cholesterol Truth}

\begin{abstract}
Chicken egg is a good source of nutrition and contains many essential amino acids, fatty acids, vitamins and minerals for healthy diets. Suggesting that high cholesterol containing foods caused high risk in the mortality of CVD resulted in "cholesterol phobia" in all over the world especially in the industrialized countries and influenced egg consumption negatively. After, no correlation between egg intake and blood cholesterol was found in the studies, American Heart Association today suggests eating one egg per day in the case of cholesterol intake $300 \mathrm{mg}$ or less. Today, it is very imperative for human nutrition to recommend egg intake which is not at the desired level because of cholesterol fear.
\end{abstract}

Key Words: Blood cholesterol, CVD, cholesterol phobia, egg consumption

\section{G R Ş}

Doğal bir besin olan ve biyolojik değeri yaklaşık \%94 olan yumurta, insan beslenmesi açısından büyük öneme sahiptir. Buna rağmen kolesterol içeriğinin yüksek bulunması ve Amerikan Kalp Birliği'nin 1970'li yıllarda yumurta tüketimini, kalp damar hastalığı (KDH) oluşum riskini artırdığı gerekçesiyle sınırlandırılması yönündeki telkinleri, tüm dünyada bireylerin yumurta tüketiminin olumsuz yönde etkilenmesine neden olmuştur. Yumurta tüketimi, Türkiye'nin de dahil olduğu birçok ülkede Dünya Sağlık Örgütü tarafından tavsiye edilen seviyesinin (yıllık kişi başına 183 adet) altındadır (Çelebi ve Karaca, 2006). Ancak; yapılan bilimsel çalışmalarda yumurta tüketiminin insanlarda kan kolesterolünü artırmadığı ve kan kolesterolü artışından diğer nedenlerin de sorumlu olabileceği bildirilmiştir (Mc Namara 2000a, b). Ayaşan ve Okan (2000) ise kişinin yumurta ya da hayvansal gıdalardan alınan kolesterole karşı verdiği tepkinin genetik olduğunu; yani sağlık problemleri olmayan kişilerin bu konudaki sansasyonel yaklaşımlardan etkilenerek paniğe kapılmalarının gereksiz olduğunu bildirmişlerdir.

\section{Kolesterol Molekülü ve Metabolizması}

Hidrofobik bir yapıya sahip ve vücutta önemli fonksiyonlara sahip olan kolesterol, karbonları sırasıyla numaralandırılmış olan alfabenin ilk dört harfi ile gösterilen (A, B, C ve D) ve "steroid nükleusu" diye adlandırılan yapıyı içeren dallanmış hidrokarbon zincirinden oluşmuştur (Şekil 1).

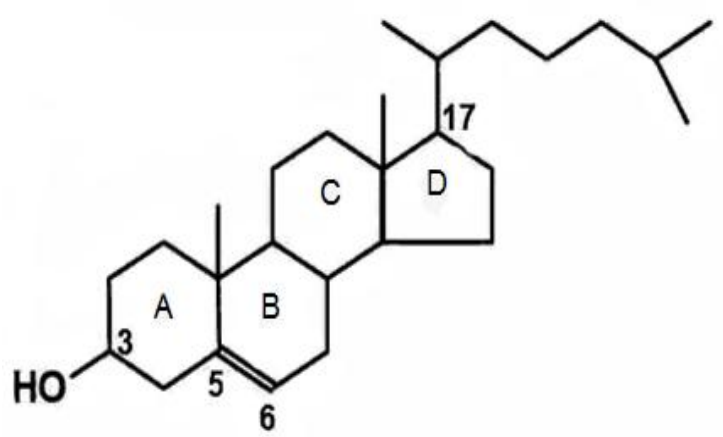

Şekil 1: Kolesterolün yapısı (Harvey ve Champe, 1997)

Yapisinda bulunan $\mathrm{OH}^{-}$grubu sayesinde hidrofilik özellik kazanmakta ve yağ asitleri ile esterleşip kan dolaşımında lipoproteinler halinde bulunmaktadır. $\mathrm{Bu}$ lipoproteinler yapısında taşıdığı yağ miktarına bağlı olarak şilomikron, çok düşük yoğunluklu lipoprotein (VLDL), düşük yoğunluklu lipoprotein (LDL) ve yüksek yoğunluklu lipoprotein (HDL) olarak isimlendirilir. Karaciğerde üretilen kolesterol ve diğer lipitler, vücuttaki diğer dokulara dağılması için VLDL içinde kana salgılanır. VLDL bulunan trigliserit ve kolesterol hücrelere aktarıldıkça VLDL'nin yapısı ve 
yoğunluğu değişir; önce IDL (intermittens density lipoproteinler) sonra da LDL'ye dönüşür.

nsanların günde yaklaşık $800 \mathrm{mg}$ ürettiği kolesterol, beyin dahil hemen hemen vücuttaki bütün hücrelerde sentez edilebilmesine rağmen; özellikle karaciğer, bağırsak, adrenal korteks, üreme organları (ovaryum ve testisler), deri ve plasentada yoğun bir şekilde sentez edilir. Diyetsel kolesterol alımının azalması durumunda özellikle karaciğer ve barsaklarda kolesterol sentezi gerçekleştirilir. Beyin hücre membran stabilitesi için gerekli olan kolesterol, yağların sindiriminde, kalsiyum ile fosforun kullanımında ve D vitamini dahil östrojen ve androjen gibi steroid hormonların sentezlenmesinde görev alır (Kaminski, 2000). Plazma kolesterolünün bir kısmı hayvansal gıdalarla sağlanırken (\%25) büyük bir kısmı da vücutta (\%75) sentezlenir (Kaminski, 2000; McKenney ve Hawkins 1995). Memeliler için esansiyel olmayan bu molekül karaciğerde basit prekürsörlerden (asetil CoA) sentez edilir (Şekil 2).

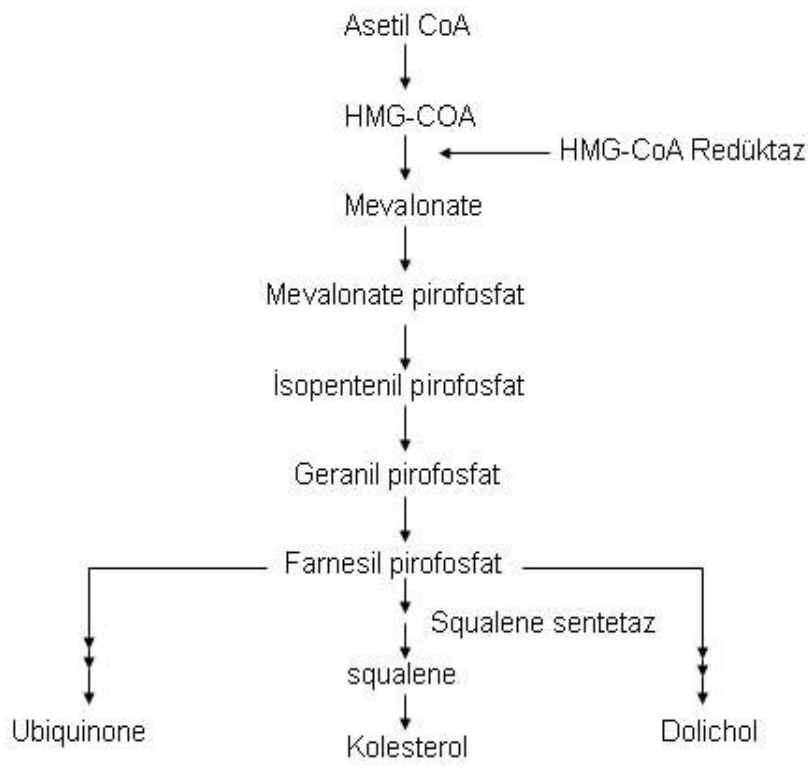

Şekil 2: Kolesterolün biyosentezi (McKenney ve Hawkins, 1995)

\section{Yumurtanın Besin Madde çeriği ve nsan Beslenmesi Açısından Önemi}

Yumurta, kaliteli ve yüksek miktarda esansiyel amino asitlerin kaynağı olmakla birlikte; diğer birçok esansiyel yağ asitleri, vitaminleri (C vitamini hariç) ve mineralleri (demir, fosfor, sodyum, klor, bakır, mağnezyum ve mangan gibi) içermesi nedeniyle bebeklerin, çocukların, yetişkinlerin ve yaşlı insanların temel besin maddelerini karşılaması bakımından oldukça önemli bir besin kaynağıdır. Özellikle de yüksek biyolojik değere (yaklaşık \%94) sahip olmasından dolayı tamamına yakını vücut tarafından kullanılır ve vücut proteinlerine dönüştürülebilir. $\mathrm{Bu}$ özelliğinden dolayı, diğer besinlerin protein kalitesinin hesaplanmasında standart olarak kullanılır (Yegani, 2003). Yumurtada proteinden elde edilen fayda \%93.7, sütte $\% 84.5$, balıkta $\% 76$, sı ğır etinde ise $\% 74.3$ dür
(Tayar, 2005). Yumurta sarısında bulunan besin maddelerinden lutein ve zeaksantin adlı karotenoidlerin yaşlı insanlarda katarakt ve ilerleyen yaşla birlikte ortaya çıkan gözde maküler dejenerasyon riskini azalttı̆̆ 1 da bildirilmiştir (Brown ve ark., 1999). Yapılan bir diğer çalışmada da yaşlılarda günde bir yumurta tüketilmesinin, serum lipid ve kolesterol konsantrasyonlarını etkilemeksizin kan serumunda lutein ve zeaksantin konsantrasyonlarını sırasıyla \%26 ve \%38 oranlarında artırdığ 1 belirlenmiştir (Goodrow ve ark., 2006). Yumurtada bulunan ve beyin gelişiminde önemli bir yeri olan diğer bir besin maddesi kolin olup, büyük bir yumurtada yaklaşık olarak $215 \mathrm{mg}$ kadar bulunur. Kolinin beyin gelişiminde ve normal fonksiyonunda önemli bir yeri olduğu bildirilmiştir (Gibbons ve Dizau, 1996). Dolayısıyla; yaşlı insanlarda yumurta tüketiminin sinırlandırılması ya da tamamen diyetten çıkarılması göz ve beyinle ilgili problemlerin oluşumuna neden olacaktır.

\section{Yumurtanın Kan Kolesterolü Üzerine Etkileri}

Yumurtanın insanlarda kan kolesterolü üzerine etkilerini araştırmak amacıyla birçok klinik ve epidemiyolojik çalışmalar yapılmıştır. Goodrow ve ark. (2006) tarafından 60 yaş ve üzeri bireylerde yapılan bir araştırmada günde 1 yumurta yiyen kişilerde serumdaki toplam kolesterol, LDL kolesterol, HDL kolesterol ve trigliserid seviyelerinin etkilenmediği bildirilmiştir. Kritchevsyk ve Kritchevsyk (2000) tarafından yapılan epidemiyolojik bir çalışmada, şeker hastası olmayan erkek ve kadın bireylerin günde 1 yumurta tüketmesiyle, koroner kalp hastalı̆̆ 1 arasında bir ilişki bulunmadığ gösterilmiştir. Toplam 90735 bireyin katılımıyla Japonya'da gerçekleştirilen bir çalışmada, günde bir yumurta tüketiminin orta yaşlı bireylerde $\mathrm{KDH}$ insidensinde artışa neden olmadığı bildirilmiştir (Nakamura ve ark., 2006). Buna rağmen, ülkemizde ve dünyada hala daha bazı sağlık profesyonelleri tarafından KDH'nın önlenmesi açısından yumurta tüketimin sınırlandırılması gerektiği konusunda tavsiyeler bulunmaktadır.

Amerikan Kalp Birliği 1970'li y1llarda yumurta tüketiminin sinırlandırılması ve diyetsel kolesterol alımının belirli düzeyde tutulması gerektiğini önermesine rağmen, bugün aynı birlik kolesterol alımının günde $\leq 300 \mathrm{mg}$ olması durumunda insanların günde bir yumurta tüketilebileceğini bildirmektedir (Farrant, 2002). Yumurtanın kan kolesterolünü etkilemediği bilimsel çalışmalarla gözlenmiştir (Song ve Kerver, 2000).

\section{Düşük Kolesterollü Yumurta}

Amerikan Kalp Birliği'nin 1970'li y1llarda yumurta tüketiminin kan kolesterolünü artırdığını bildirmesinden sonra insanlarda "yumurta" denince akla yüksek kolesterol içeren bir gida olarak gelmesi "yumurta fobisi"ne dolayısıyla da tüm dünyada yumurta tüketimlerinde çok önemli düşüşlere neden olmuştur. Bu 
nedenle; kolesterol fobisinden kaynaklanan yumurta tüketimindeki düşüşleri azaltmak amacıyla, düşük kolesterollü yumurta üretilmesine yönelik çalışmalar hız kazanmıştır. Yıllar önce yapılan çalışmalar, yumurtada yaklaşık olarak $274 \mathrm{mg}$ kolesterol bulunduğunu göstermiştir (Stadelman ve ark., 1988). Yumurtadaki bu kolesterol miktarı, yapılan besleme çalışmaları ile biraz daha aşağılara çekilmiştir. Bugün ortalama bir yumurtada yaklaşı $213 \mathrm{mg}$ kolesterol bulunur.

Tüketici isteğine bağlı olarak yumurtadaki kolesterol seviyesini düşürmek amacıyla yapılan birçok çalışma, yumurta kolesterolundaki azalmanın sınırlı olduğunu göstermiştir (Naber, 1983; Elkin ve ark., 1999, Elkin ve ark., 2003; Elkin, 2007).

Yumurta sarısı kolesterol düzeyini etkileyen faktörler; genotip, yaş, yetiştirme tipi ve yemin yapısıdır (Hargis, 1988). Yumurta sarısı kolesterol içeriğini azaltmak için genetik seleksiyonlar yapılmış ancak istenen başarı elde edilememiştir. Sim ve ark. (1984), Yucca schotti kaktüsünden elde edilen saponin katkılı rasyonla beslenen yumurta tavuklarında kolesterol düzeyinde önemli bir değişme olmaksızın yumurta üretimi ve yem tüketiminin azaldığını ifade etmiş̧lerdir. Saponin kaynağı olarak Yucca schidigera tozu kullanıldığında ise, yemden yararlanma ve yumurta veriminin belirli bir düzeyde arttığını, yumurta kolesterol içeriğinin de önemli düzeyde azaldığını bildirmişlerdir.

Uyanık ve ark. (2001), yumurta tavuğu rasyonlarına krom ilavesinin yumurta verimi, kalitesi, yumurta sarıs1 kolesterolü ve bazı serum parametreleri üzerine etkisini belirlemek üzere bir araştırma yapmışlardır. Araştırma sonunda rasyona krom ilavesinin yumurta kabuk kalitesini olumlu etkilediği, diğer verim parametreleri üzerinde etkili olmadığı, serum trigliserid ve yumurta sarıs1 kolesterol seviyesini önemli, toplam kan kolesterolünü ise önemsiz seviyede azalttı $\breve{g}_{1}$ tespit edilmiştir. Yapılan diğer bir araştırmada yumurta tavuğu rasyonlarına 200, 400, 600 ve 800 ppb düzeylerinde organik krom ilave edilmiştir. Rasyona 600 ve 800 ppb organik krom ilave edilen tavukların kan serumlarında ve bunlardan elde edilen yumurtalarda kolesterolün istatistiki olarak önemli seviyede azaldığ 1 belirlenmiştir (Çakır ve Yalçın, 2004).

Bakırın değişik formlarının rasyonlarda kullanımı sonucunda da yumurta kolesterolü düşürülebilmektedir. Bakırın kolesterolü düşürücü etki mekanizması kesin olarak bilinmemekle birlikte, HMG CoA redüktaz enzimini inhibe ederek bu etkiyi oluşturduğu düşünülmektedir. Bu amaçla farklı düzeylerde bakırın $(50,150$ ve $250 \mathrm{mg} / \mathrm{kg})$ yumurta kolesterol düzeyine etkisi incelenmiştir. Araştırma sonucunda $250 \mathrm{mg} / \mathrm{kg}$ bakır eklenen grupta yumurta ve plazma kolesterol düzeyinin sirasiyla \% 14 ve \% 20 oranlarına kadar azaltılabileceği ve $250 \mathrm{mg} / \mathrm{kg}$ dozunda rasyona eklenen bakırın yumurta sarısındaki kolesterolü düşürmede daha etkili olduğu bildirilmiştir (Al Ankari ve ark., 1998).

\section{SONUC}

Yumurta insan beslenmesinde çok önemli yeri olan bir besin maddesidir. Esansiyel amino asitler, esansiyel yağ asitler, mineraller, yağda ve suda çözünen vitaminler (C vitamini hariç) bakımından besin deposu olarak kabul edilen tavuk yumurtasının, insanlarda kan kolesterolünì etkilemediği bilimsel çalışmalarda bildirilmiştir. Dolayısıyla; günlük alınacak enerji, sabit kalmak şartıyla günde 1 yumurtanın tüketilmesi sağlıklı beslenme açısından son derece önemlidir.

\section{KAYNAKLAR}

Al Ankari, A., Najib, H., Al Hozab, A. 1998. Yolk and serum cholesterol and production traits, as affected by incorporating a supraoptimal amount of copper in the diet of leghorn hen. Br. Poult. Sci. 39: 393-397.

Ayaşan, T., Okan, F., 2000. Kolesterol, Atherosclerosis ve Yumurta Üçgeni. Uluslararası Hayvan Besleme Kongresi. Kongre Kitab1 s. 618-625. Süleyman Demirel Üniversitesi, Isparta.

Brown, L., Rimm, E.B., Seddon, J.M., Giovannucci, E.L., Chasan-Taber, L., Spiegelmen, D., Willnett W.C., Hankinson, S.E. 1999., A prospective study carotenoid intake and risk of cataract exraction in US men. Am. J. Clin. Nutr. 70: 517-524

Çakır, S., Yalçın, S. 2004. Yumurta kolesterol düzeyine etki eden faktörler. Lalahan Hay. Araşt. Enst. Derg. 44: 51-63.

Çelebi, Ş., Karaca, H. 2006. Yumurtanın Besin Değeri, Kolesterol çeriği ve Yumurtayı n-3 yağ asitleri Bakımından Zenginleştirmeye Yönelik Çalışmaları. Atatürk Üniv. Ziraat Fak. Derg. 37: 257-265.

Elkin, R. G., Yan, Z., Zhong, Y., Donkin, S. S., Buhman, K. K., Story, J. A., Turek, J. J., Porter, R. E. Anderson, M., Homan, R., Newton, R. S. 1999. Select 3-hydroxy-3 methylglutarylcoenzyme A reductase inhibitors vary in their ability to reduce egg yolk cholesterol levels in laying hens through alteration of hepatic cholesterol biosynthesis and plasma VLDL composition. J. Nutr. 129: 1010-1019.

Elkin, R. G., Furumoto, E. J., Thomas, C. R. 2003. Assessment of egg nutrient compositional changes and residue in eggs, tissues, and excreta following oral administration of atorvastatin to laying hens. $\mathbf{J}$. Agric. Food. Chem. 51: 3473-3481.

Elkin, R.G., 2007. Reducing shell egg cholesterol content. II. Review of approaches utilizing nonnutritive dietary factors or pharmacological agents and an examination of emerging strategies. World's Poult. Sci. 63: 5-32.

Farrant, J. 2002. No limit on egg eating. Poult. World 156 (11) p. 14.

Gibbons, G.H., Dizau, V.J. 1996. Molecular therapies for vascular diseases. Science 272: 689-693. 
Goodrow, E.F., Wilson, T.A., Houde, S.C., Vishwanathan, R., Scollin, P.A., Handelman, G., Nicolosi, R.J. 2006. Consumption of one egg per day increases serum lutein and zeaxanthin concentrations in older adults without altering serum lipid and lipoprotein cholesterol concentrations. J. Nutr. 136: 2519-24.

Hargis, P.S. 1988. Modifying egg yolk cholesterol in the domestic fowl: A review. World's Poult. Sci. J. 36: 429-454.

Harvey, R.A., Champe, P.C. 1997. Lipincott's Illustrated Reviews Serisinden: Biyokimya. 2. Bask1. Nobel Tıp Kitabevleri Ltd. Şti. stanbul.

Kaminski, M.V., 2000. Giving eggs a bad rap: what physcians should know and tell their patients about cholesterol. pp. 93-111. Egg Nutrition and Biotechnology.

Kritchevsky, S.B., Kritchevsky, D. 2000. Egg consumption and coronary heart disease: An epidemiologic overview. J. Am. Coll. of Nutr. 19: 549-555.

McKenney, J.M., Hawkins, D.W. 1995. Handbook on the Management of Lipid Disorders. National Pharmacy Cholesterol Council. Springfield, NJ.

McNamara, D.J. 2000a. Dietary cholesterol and arteriosclerosis. Biochim. Biophys. Acta 1529: 310-320.

McNamara, D.J. 2000b. The impact of egg limitations on coronary heart disease risk: Do the number add up? J. Am. Coll. of Nutr. 19 (5): 540-548.
Naber, E.C. 1983. Nutrient and drug effects on cholesterol metabolism in the laying hen. Poult. Sci. 42: 2486-2493.

Nakamura, Y., Iso, H., Kita, Y., Ueshima, H., Okada, K. Konishi, M., Inoue, M., Tsugane, S. 2006. Egg consumption, serum total cholesterol concentrations and coronary heart disease incidence: Japan Public Health Center-based prospective study. Br. J. of Nutr. 96: 921928.

Sim J.S., Kitts, W.D., Bragg, D.B. 1984. Effect of dietary saponin on egg cholesterol level and laying hen performance. Can. J. Anim. Sci.64: 977-984.

Song, W.O., Kerver. J. M. 2000. Nutritional contribution of eggs to American diets. J. Am. Coll. of Nutr. 19 (5): 556-562.

Stadelman, W.J., Olson, V.M., Shemwell, G.A., Pasch, S. 1988. Nutritional value of eggs. Chapter 2. In: Egg and Poultry-Meat Processing. Ellis Horwood Ltd, Chichester, England.

Tayar, M. 2013. Yumurta Hijyeni. Erişim 20.10.2013. http://mtayar.home.uludag.edu.tr/yumurtahijyeni.htm.

Uyanık, F., Kaya, Ş., Kolsuz, A.H., Eren, M., Şahin, N. 2001. The effect of chromium supplementation on egg production, egg quality and some serum parameters in laying hens. IX. Symposium on the Quality of Eggs and Egg Products. s. 231 Kuşadası, Turkey.

Yegani, M. 2003. A new look at egg consumption. World Poult. 19: 25-27. 